\title{
Servicescape and Group References in Determining Hedonic Value and Its Implication on Impulsive Buying
}

\author{
Aa Willy Nugraha ${ }^{1^{*}}$ and Yusuf Abdullah ${ }^{2}$ \\ ${ }^{1}$ Politeknik LP3I, Tasikmalaya, Indonesia \\ ${ }^{2}$ Universitas SIliwangi, Tasikmalaya, Indonesia
}

\begin{abstract}
Consumer decision in purchasing product generally depend on his/her needs. The impulsive buying as the purchasing activity, in contrast, was based on the emotional encouragement. In the other hand, customer got pleasant experiences after purchasing that product spontaneously. That is a hedonic value which is customer circumstances encouraging buying decision. The study objectives were to know whether the servicescape and reference group could be determinant factors of hedonic value and impulsive buying activity in Plaza Asia Tasikmalaya. This study was quantitative research approach, a statistical data based, with survey method. The data collected was by fulfiling questionnaire by respondent with convenience sampling technique, a type of non-probability sampling method, which was taken from a group of people easy to contact or reach. The literature studies also applied to enrich the explanation of the variables analyzed. The sample size was 255 visitors of Plaza Asia Tasikmalaya. Then, the data was analyzed using the Structural Equation Modeling (SEM) technique to know the influence between variables directly and indirectly. The result indicated that the servicescape and reference group had effects significantly to hedonic value and had implication on impulse buying partially and simultaneously.
\end{abstract}

Keywords: Hedonic Value, Impulsive Buying, Reference Group, Servicescape.

\section{Introduction}

Globalization and world trade liberalization implicated rise changes in the business environment, especially in developing countries such as Indonesia. Therefore, every company must adapt to existing changes and have its own competitive advantage. Competitive advantage can be achieved through value creation of the retail/store effort such as comfortable store situation, facilities and services so that customer satisfaction can be achieved. This results in a long-term relationship between the customer and the company. The retail business sector is one of the business sectors that is affected by global economic developments, even it becomes a measure of a country's economic success. In Indonesia, competition for retail business such as supermarkets, minimarket, and hypermarkets is increasingly mushrooming. According to AC Nielsen in the Industry Update of Bank Mandiri (2012) in Yuliartini and Sulistyawati (2013) stated that during the 2004 to 2010 period, the average retail growth per year in that period was $20.2 \%$ of minimarkets followed by convenience stores amounted to $19.6 \%$. Hypermarkets amounted to $14.6 \%$ and supermarket only 2.6\%. The Indonesian Retail Entrepreneurs Association (APRINDO) in HaloMoney research explained that the growth of the retail industry was below 5\% during January to June 2017. In 2018, Indonesia is in eighth position or down three places from 2016. Kearney, A global management consulting, stated that retail sales in Indonesia reached US $\$ 350$ billion this year, or only an increase of 8.02 percent from last year (Angga Yuniar, 2017).

The business page of liputan6.com reported that in 2017 there were several modern retailers that experienced bankrupt (Angga Yuniar, 2017). This is due to

* Corresponding author. Email address: aawillynugraha@gmail.com 
changes in consumption patterns and a decrease in people's purchasing power. Some of the modern retail outlets that have closed are Lotus, seven leven, Debenhams, Matahari and Ramayana (Partially closed). There are several things that make the retail industry important to study, namely: (1) the implications of retail in the global economy. It because retail sales and labor absorption are key to the global economy; (2) the retail function in the distribution chain, namely to act as a liaison between the final consumer and the manufacturer and wholesaler; (3) the relationship between retailers and customers (Berman and Evans, 2010). In the first semester of 2020, Indonesia has a population of 268.5 million people of the population (Dian, 2020), and based on statement of the Indonesia Minister of Trade that was fifty percent of the population is consumptive (Thomas, 2016). Thus, retail businesses rely on people's consumption patterns as a business opportunity. However, the development of ecommerce has caused a shift in people's consumption patterns, thus it becomes a big challenge for retail businesses. Thus, retailers need to create value added value such as an outlet environment (servicescape) to create a good impression during a visit.

Tasikmalaya is administratively located in the province of West Java with several excellent resources and a creative economy potential, so that it is one of the regions in West Java that has a lot of business potential including retail. There are many modern retailers scattered in Tasikmalaya, especially large retailers located in downtown Tasikmalaya. The author will only examine large retailers, such as supermarket. A supermarket is a type of shopping center that is architecturally a closed building with regulated temperatures and has paths to walk regularly so that it is between small shops facing each other. It provides household needs, electronic equipment, clothing, gadgets, basic necessities, ATM centers, restaurants, hotels and water recreation /tourism facilities namely Teejay Water Park and office facilities and XXI cinema.

Then, author was interested in choosing Plaza Asia Tasikmalaya as a research object because this supermarket is the largest supermarket in East Priangan and located at center of Tasikmalaya City. In addition, the parameters of a city are classified as a "big city" not only by the establishment of factories, crowded traditional markets, and the density of population, but whether there is a shopping center even though it only has a small place or just a place for goods and services transaction, but as a display of the latest cultural instruments so that consumerism is spoiled. Supermarket becomes a perfect communication space, as a form of interpersonal communication to mass communication taking place simultaneously. In addition, interactions between community members take place more dynamically than anywhere else in Tasikmalaya City. The integrated facilities provided such as hotel (Asri Hotel) and children's playgrounds, business center, and other recreation destinations are available. All facilities provided by Plaza Asia indirectly make the people feel comfort and enjoy. Public enthusiasm is necessary for the presence of Plaza Asia, this is evidenced by the increase in the number of visitors in its first year even by event organizers carried out various events at Plaza Asia Tasikmalaya. The following is a graph of the number of visits from 2017 to 2019 , as follows:

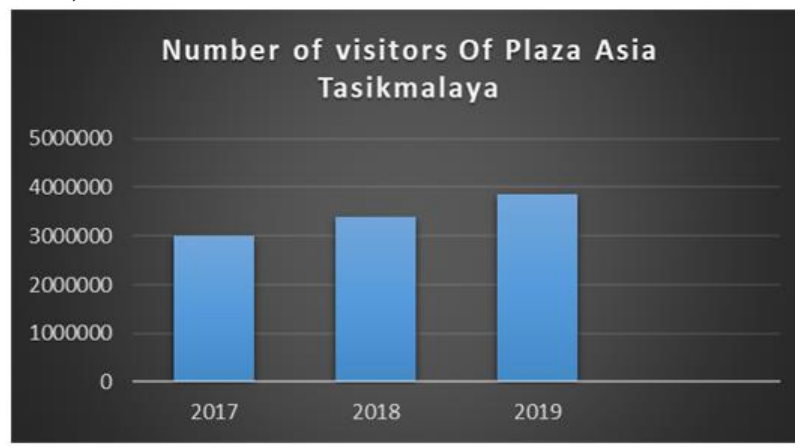

Figure 1 Numbers of Plaza Asia Visitor in 2017 - 2019 Source: Plaza Asia Tasikmalaya 
Based on the Figure above, the number of visit in 2017 was 3,003,265 visitors, in 2018 experienced increase 10 percent to 3,393,689 visitors and in the period of 2019 the number of visit was increasingly to $3,869,273$ visitors. Then, the author was interested in investigating the factors causing the growth of the number of visitor in Plaza Asia Tasikmalaya. The visitor behavior in purchasing product including hedonic value and impulsive buying were predicted by factors affecting it. They were servicescape and reference group. The impulsive buying is a shopping behavior that occurs unplanned, emotionally interested, in which the decision-making process. Supermarket, Plaza Asia Tasikmalaya, is a pleasant place for several consumer in making enjoyment and fulfilling them needs. The environment due to the environmental and psychological issues linked with the visitor. The experience feelings of anxiety, stress and excitement which make them react in unusual ways. The Plaza's environments therefore differ from more day-to-day channels of distribution. Consequently, retailers' approaches must also differ in order to optimize performance. There is evidence of a considerable impulse bulying effect in Plaza Asia Tasikmalaya which caused by hedonic value, servicescape and reference group. The impulse was effected by the factors mentioned was wished to increase the purchase decision.

Beside it, the emotional encouragement had a role in supporting the customer decision in buying the product. The hedonic value as the value of shopping experiences including fantasy, arousal, sensory-stimulation, enjoyment, pleasure, curiosity, and entertainment in buying product also related with the emotional sense supporting the impulse buying. The previous research was by Rachmawati in Yistiani, et al (2012) who stated that consumers are more likely to be involved in impulse buying when they are motivated by hedonic desires or economic reasons, such as pleasure, fantasy, and social or emotional satisfaction.

Supermarket, as the shopping place, consists of variety of stores and brands need a servicescape to be more attractive. The servicescape is the communication way of store atmosphere in which the services are assembled, the place where the consumer and seller are interact each other, and it is a combination of the tangible commodities and service. This atmosphere created by the store in Supermarket will give the influence to the hedonic value of the consumer and cause the impulse buying. The earlier research was by Yistiani, et al (2012) that stated the servicescape including the atmosphere store will affect the hedonic value, so does the impulse buying will be implicated. Other factor which was being determinant aspect was a group reference, means recommendation of buying the product. The hedonic value and impulse buying will be affected by it. The research about it was by Sastradhi and Widagda K (2013) which stated that the atmosphere of outlets and reference groups has an influence on hedonic value and impulse buying. Other study was by Dedeoglu, et al (2018) that stated that servicescape can affect the hedonic value of consumer.

Based on the research background explained, this study entitled servicescape and reference group in determining hedonic value and its implications of impulsive buying. So that the main objectives of this study were analyzing the influence of servicescape and reference group on the hedonic value and its implication on impulsive buying of Plaza Asia Tasikmalaya visitors partially and simultaneously.

\section{Literature Study/Hypotheses Development}

In this study, the literatures related to the study were about servicescape, reference group, hedonic value, and impulsive buying.

\section{Impulsive Buying}

Bayley and Nancarrow (in Yistiani, et al, 2012) defined impulsive buying as shopping behavior that occurs unplanned, emotionally interested, in which the decision-making process is carried out quickly without thinking wisely and considering all available information and alternatives. Shiffman \& Kanuk (2010) stated impulsive 
buying was happening when the consumers who like shopping find the innovation and creative sales promotion used by retail shop. The big discount aimed to target the customer who liked the promotional price and so on. Impulsive buying occur when consumers see a certain product or brand, then consumers become interested in getting it, usually because of an attractive stimulus from the store (Utami, 2010). Purchasing activities held without prior shopping intentions and without considering the results of the purchase. Or it can also be said of a sudden, strong, persistent urge to buy something directly, without paying much attention to the consequences (Mowen and Minor, 2012). Impulsive buying is a sudden desire to buy a product without planning or prior purchase intentions without much consideration and tends to use emotions in the purchasing decision-making process (Octa, et al, 2014). Impulsive buying can be said to be a sudden impulse with full force, persistence and not being planned to buy something directly, without paying much attention to the consequences (Rachmawati in Yistiani, et al, 2012).

Thus, it can be concluded that impulsive buying is a shopping behavior that occurs unplanned, attracted emotionally, where the decision-making process is done quickly without thinking further. There are several indicators that can measure impulsive buying, there are (Yistiani, et al, 2012): (1) Spontaneity, which is a situation where customers often buy something without being planned first; (2) Purchasing without thinking consequences, which is a condition where customers often make purchases without thinking about the consequences of the purchases made; (3) Rush purchases, is a situation where customers often feel that they are too hasty in buying something; (4) Emotional, customer assessment where customers do shopping activities influenced by the consumer's emotional state.

\section{Hedonic Value}

Hedonism is a Greek word "hedone" which means pleasure or enjoyment. Hedonic consumption reflects the value of shopping experiences such as fantasy, arousal, sensory-stimulation, enjoyment, pleasure, curiosity, and entertainment (Scarpi in Octa, et al, 2014). The hedonic value of consumption is a consumption experience related to feelings, fantasies, pleasures, and the senses, where these experiences affect one's emotions (Asnawati and Wahyuni, 2018). Hedonic value is a feeling of pleasure when someone is shopping to find an item that is good and valuable to him, where the good goods can be defined by a low price, advantage, quality and others. In addition, hedonic motivation is a purchasing activity that is driven by behaviors related to the five senses, delusions and emotions that make pleasure and material enjoyment the main goal of life (Darma and Japarianto, 2014).

Hedonic consumption as an aspect of behavior related to multi-sensory, fantasy, and emotional aspects of consumption. This view shows that consumption is driven by the pleasure in using the product. Hedonic shopping motivation is similar to utilitarian shopping motive, but only purchasing decisions are related to fulfilling hedonic shopping values, such as pleasant experiences, entertainment, and fantasies. Hedonic shopping value refers to the sense of enjoyment and pleasure that consumers receive from all buying experiences related to shopping activities (Octa, et al, 2014). Thus, it can be concluded that hedonic value is an emotional feeling that consumers feel from their shopping experience. Scarpi in Octa, et al, (2014) stated indicators of hedonic value as follow: (1) enjoyment, means customers enjoy shopping activities; (2) Pleasure, means customers feel happy when visiting and when shopping; (3) Curiosity, namely by making visits to outlets, customers can help fulfill their curiosity about the latest products; (4) Entertainment, means a shopping as an entertainment; (5) Social interaction, where customers can make social interactions during shopping.

\section{Servicescape}

Bitner in Rashid, et al (2015) stated that servicescape refer to build environtment or man-made physical surrounding that opposed to the natural (social environtment). 
Ballantine, et al (2010) stated that designed shopping environment with specific purposes such as creating emotional of the customer would make purchase decision. As defined by Bitner in Dedeoglu, et al (2018), the servicescape is an overall or holistic structuring of environmental dimension rather than a single component. It can help explain cognitive responses that affect people's opinions about a place, other people, and or product. Heide, et al in Dedeoglu, et al (2018) stated that atmosphere, including heat, scent, voice, music, and lightning. This atmosphere is a part of ambience.

The physical dimension, according to research of Zeithaml in Rashid, et al (2015), is a tangible cues that associated with service quality including all aspect of the services provider physical facilities exterior, interior, and other tangible factors. The dimensions of servicescape according to research of Rashid, et al (2015) are (1) ambient condition; (2) functionality; (3) Explicit cues; and (4) implicit cues.

\section{Reference Group}

A reference group is someone who is directly (face-to-face) or indirectly influence on that person's attitude or behavior (Kotler and Keller, 2016). In connection with the social environment, it is a presence of other people participating in shopping activity such as family or friends that are influencing consumer decision in shopping. Consumers who shop with family or friends usually don't just buy products, but also look for fun Dedeoglu, et al (2018) Based on the definitions by several experts above, it can be concluded that the reference group is a group that can influence consumer attitudes and behavior directly or indirectly. In this study, the indicators of the reference group are (Indrawati, 2017) (1) primary group, including family, friends, neighbors and colleagues; (2) secondary groups, including community, religious, professional, and trade union groups; (3) Aspirational Group, namely the group that the person wants to join; (4) Dissociative Group, is a group that values and behavior rejected by the person.

The research hypothesis were (1) servicescape and reference groups has an effect on the hedonic value of Plaza Asia Tasikmalaya visitors, simultaneously or partially; (2) servicescape, reference group and hedonic value influence the impulsive buying of Plaza Asia Tasikmalaya visitors simultaneously and partially.

\section{Research Methodology}

The research method used was survey method with quantitative approach. Verification research method was also used also in confirming the current study and the previous study. This research also aimed to determine the relationship between research variables and to examine the effect of servicescape and reference groups on hedonic value and its implications of impulsive buying of visitors of Plaza Asia Tasikmalaya. This study used structural equation model (SEM) analysis techniques which were used to determine how much the relationship between the variables studied. The statistical tests included the suitability of the model analysis, normality test, the interpretation of the estimated value of the model and the final stage in testing the hypothesis and knowing direct and indirect effects. This analysis technique was many advantages, were analyzing not only the latent variables but also its observed variables. The analysis was including normality testing, goodness of fit analysis. The results were obtained, then it would be analyzed and finally stated conclusions and suggestions. The sample size was 255 visitors of Plaza Asia Tasikmalaya. The qualified respondent was chosen from how often they visit the Plaza. The sample size was counted by 15 times of the number of observed variables (17 observed variables x 15) as explained by Singgih Santoso (2015). The sampling technique used convenience sampling technique. This sampling technique is a type of no-probability sampling method which was taken from a group of people easy to contact or reach. The data collection technique was by distributing questionnaire and the respondent filled it on the spot. Beside it, the secondary data was collected by literature study from the electronic journals, Plaza Asia management and articles in the internet 
AFEBI Management and Business Review (AMBR)

Vol.05 No.02 December 2020

\section{Result}

In the beginning of data analysis, the author firstly use normality test, model fit test, parameter evaluation and finally hypothesis test.

\section{A. Normality Test}

Based on the normality testing criteria, it could be concluded that the data used for the exogenous construct was normally distributed at both the univariate and multivariate levels, as shown in the following table.

Table 1 Data Normality Testing

\begin{tabular}{ccccccc}
\hline Observed VAR & Min & Max & Skew & CR & Kurtosis & CR \\
\hline $\mathbf{( 1 )}$ & $\mathbf{( 2 )}$ & $\mathbf{( 3 )}$ & $\mathbf{( 4 )}$ & $\mathbf{( 5 )}$ & $\mathbf{( 6 )}$ & \multicolumn{1}{c}{$\mathbf{( 7 )}$} \\
\hline Item 1 & 1.000 & 5.000 & -.554 & -1.173 & .153 & .577 \\
Item 2 & 1.000 & 5.000 & -.607 & -2.410 & .170 & .588 \\
Item 3 & 1.000 & 5.000 & -.646 & -2.466 & .250 & .824 \\
Item 4 & 1.000 & 5.000 & -.923 & -2.140 & 1.882 & 2.083 \\
Item 5 & 1.000 & 5.000 & -.847 & -2.380 & 1.146 & 2.315 \\
Item 6 & 1.000 & 5.000 & -.576 & -1.335 & .661 & .986 \\
Item 7 & 1.000 & 5.000 & -.779 & -2.561 & .996 & 1.047 \\
Item 8 & 1.000 & 5.000 & -.722 & -2.433 & .360 & .396 \\
\hline $\mathbf{( 1 )}$ & $(\mathbf{2})$ & $\mathbf{( 3 )}$ & $\mathbf{( 4 )}$ & $\mathbf{( 5 )}$ & $\mathbf{( 6 )}$ & \multicolumn{1}{c}{$\mathbf{( 7 )}$} \\
\hline Item 9 & 1.000 & 5.000 & -.155 & -.698 & 1.508 & 1.570 \\
Item 10 & 1.000 & 5.000 & -.737 & -2.545 & 1.594 & 2.229 \\
Item 11 & 1.000 & 5.000 & -.594 & -1.468 & 1.071 & 2.029 \\
Item 12 & 1.000 & 5.000 & -.686 & -2.163 & .981 & 1.093 \\
Item 13 & 1.000 & 5.000 & -.874 & -2.570 & 1.375 & 1.928 \\
Item 14 & 2.000 & 5.000 & -.192 & -1.103 & .654 & .461 \\
Item 15 & 1.000 & 5.000 & -.431 & -1.446 & .757 & .849 \\
Item 16 & 1.000 & 5.000 & -.446 & -1.357 & 1.484 & 2.385 \\
Item 17 & 1.000 & 5.000 & -.840 & -1.323 & 1.889 & 2.108 \\
\hline & Multivariate & & & 24.296 & 15.342
\end{tabular}

Source: Data Analysis (2020)

Based on the information of the table above, the univariate skewness value was greater than 3 and none of the univariate kurtosis exceeds 10 as suggested by Kline (2011). This condition is supported by the value of the critical ratio (CR) for skewness and kurtosis for each variable, none of which is greater than \pm 2.58 , so it can be concluded that the data is normally distributed at the univariate and multivariate levels.

\section{B. Model Fit Test}

Model suitability test can be seen from the table below:

Table 2. The Goodness of Fit Index Criteria

\begin{tabular}{cccc}
\hline Criteria & Analysis Results & Critical Value & Model Evaluation \\
\hline$\chi^{2}-$ Chi-square & 155.853 & $<341.395$ & Good fit \\
\hline Significance Probability & 0.472 & $\geq 0.05$ & Good fit \\
\hline RMSEA & 0.033 & $\leq 0.08$ & Good fit \\
\hline GFI & 0.949 & $\geq 0.90$ & Good fit \\
\hline AGFI & 0.931 & $\geq 0.90$ & Good fit \\
\hline CMIN / DF & 1.379 & $\leq 2.00$ & Acceptable fit \\
\hline TLI & 0.961 & $\geq 0.95$ & Good fit \\
\hline CFI & 1.000 & $\geq 0.95$ & Good fit
\end{tabular}

Source: Data Analysis (2020) 
Based on the data analysis result, the model was fit (good level of acceptance). The value of $\chi^{2}$-Chi-square was 155.853 which was smaller than 341.395 (Chi-Square table). This meant that the research model was good fit. The value of significance probability was 0.472 is greater than 0.05 . This means that the research model was good fit. The RMSEA value was 0.033 less equal to 0.08 . This means that the research model was good fit. The value of GFI and AGFI respectively were 0.949 and 0.931 , which was greater than 0.90 which mean that the research model was good fit. The CMIN/DF value was 1.379 smaller than 2.00 which mean good fit. Meanwhile, the TLI and CFI values were 0.961 and 0.958 greater than 0.95 , which means that the research model is fit.

\section{Parameter Evaluation} follow:

The parameter estimates result by SEM analysis was served in table 3. as

Table 3 Parameter Estimates

\begin{tabular}{|c|c|c|c|c|c|}
\hline Description & $\begin{array}{c}\text { Regression Weights: } \\
\text { Estimate (b) }\end{array}$ & $\begin{array}{c}\text { Standardized } \\
\text { Regression Weights : } \\
\text { Estimate }(\beta)\end{array}$ & SE & CR & $\mathbf{P}$ \\
\hline (1) & (2) & (3) & (4) & (5) & (6) \\
\hline $\mathrm{SC} \rightarrow \mathrm{HV}$ & .362 & .541 & .409 & .886 & $* * *$ \\
\hline $\mathrm{RG} \rightarrow \mathrm{HV}$ & .276 & .422 & .296 & 1.945 & .003 \\
\hline $\mathrm{HV} \rightarrow \mathrm{IB}$ & .389 & .420 & .379 & 1.025 & $* * *$ \\
\hline $\mathrm{SC} \rightarrow \mathrm{IB}$ & .242 & .501 & .400 & .605 & $* * *$ \\
\hline $\mathrm{GR} \rightarrow \mathrm{IB}$ & .376 & .204 & .305 & 1.230 & $* * *$ \\
\hline SMC (1) & & .713 & & & \\
\hline SMC (2) & & .752 & & & \\
\hline
\end{tabular}

Source: Data Analysis (2020)

Based on the analysis result it could be explained that the regression coefficient (Standardized Regression Weights) of the servicescape variable on the hedonic value was 0.541 , while the regression coefficient for the reference group variable on the hedonic value variable was 0.422 . This meant that the servicescape was more dominant in influencing the hedonic value of visitors of Plaza Asia Tasikmalaya. Meanwhile, to find out the estimated value of the servicescape variable and the reference group for the hedonic value, it can be seen from the Squared Multiple Correlation (SMC) or $\mathrm{R}^{2}$, which was a value of 0.713 . This value was the amount of influence simultaneously between the servicescape variable and the reference group on the hedonic value. It meant that the influence of servicescape and reference groups affected the hedonic value of visitors of Plaza Asia Tasikmalaya was 71.3\%.

The regression coefficient (Standardized Regression Weights) of the servicescape variable on impulsive buying was 0.501 while the regression coefficient for the reference group variable on the impulsive purchasing variable was 0.204 . The regression value of the hedonic value variable on impulsive buying is 0.420 . This means that the outlet atmosphere variable is more dominant in influencing the impulsive purchases of Plaza Asia Tasikmalaya visitors. For knowing how the estimated value of the servicescape variable, reference groups and hedonic value toward impulse buying could be seen from the Squared Multiple Correlation (SMC) or $\mathrm{R}^{2}$ value was 0.752 . This value was the amount of influence simultaneously between the servicescape variables, the reference group and the hedonic value on impulsive buying. It meant that the influence of servicescape, reference groups and hedonic value affected impulsive buying of Plaza Asia Tasikmalaya visitors was $75.2 \%$. Furthermore, to determine the direct effect and indirect effect could be seen from the following table: 
AFEBI Management and Business Review (AMBR)

Vol.05 No.02 December 2020

Table 4 Direct and Indirect Effects

\begin{tabular}{|c|c|c|c|}
\hline Information & Direct Influence & Indirect Influence & Total Effect \\
\hline $\mathrm{X}_{1} \rightarrow \mathrm{Y}_{1}$ & $0.541 \times 0.541$ & - & 0.293 \\
\hline $\mathrm{X}_{1} \rightarrow \mathrm{X}_{2} \rightarrow \mathrm{Y}_{1}$ & - & $0.541 \times 0.53 \times 0.422$ & 0.121 \\
\hline \multicolumn{3}{|c|}{ Total $X_{1} \rightarrow Y_{1}$} & 0.414 \\
\hline $\mathrm{X}_{2} \rightarrow \mathrm{Y}_{1}$ & $0.422 \times 0.422$ & - & 0.178 \\
\hline $\mathrm{X}_{2} \rightarrow \mathrm{X}_{1} \rightarrow \mathrm{Y}_{1}$ & . & $0.541 \times 0.53 \times 0.422$ & 0.121 \\
\hline \multicolumn{3}{|c|}{ Total effect $\mathrm{X}_{2} \rightarrow \mathrm{Y}_{1}$} & 0.299 \\
\hline \multicolumn{3}{|c|}{ Squared Multiple Correlation $\left(\mathrm{R}^{2}\right)$} & 0.713 \\
\hline
\end{tabular}

Notes: $\mathrm{X}_{1}=$ servicescape; $\mathrm{X}_{2}=$ reference group; $\mathrm{X}_{2}=$ reference group; $\mathrm{Y}_{1}=$ hedonic value

Source: Data Analysis (2020)

Based on the table above, it can be explained that the direct effect of the servicescape on the hedonic value was 0.293 , the indirect effect of the servicescape on the hedonic value through the reference group was 0.121 , so that the total influence of the servicescape on the hedonic value was 0.414 . The direct effect of the reference group on the hedonic value was 0.178 , the indirect effect of the reference group on the hedonic value through the servicescape was 0.121 , so the total effect of the reference group on the hedonic value was 0.299. The total influence of the servicescape and reference group on the hedonic value was 0.713 . Then it could be concluded that the influence of the servicescape was more dominant in influencing the hedonic value.

\section{Discussion}

The servicescape including ambient condition, functionality, explicit cues and implicit cues of Plaza Asia Tasikmalaya which could provide special satisfaction to visitors in creating hedonic value. The servicescape created by Plaza Asia Tasikmalaya will make visitors feel comfortable when visiting the Plaza Asia Tasikmalaya.This finding was tested by interpreting the critical ratio (CR) and probability values. Based on the parameter estimation, the $\mathrm{CR}$ value of the servicescape variable on the hedonic value was 0.886 which met the requirements, was between \pm 2.58 and the probability value of 0.000 which met the requirements was less than 0.05 . This meant that the servicescape had a significant effect on the hedonic value of visitors of Plaza Asia Tasikmalaya. Thus hypothesis 1 in this study was proven. The results were in line with the research of Yistiani et al. (2012) and Dedeoglu, et al (2018) which stated that servicescape had a significant effect on customer hedonic value. Meanwhile, this research conducted by Lin (2016) also stated that servicescape affected consumer experience, then after it, the top of mind of consumer will be created. Beside it, pleasure will be created which refers to consumer pleasure when in the supermarket. Reference group including family, friends, idols and other social groups that can influence hedonic values when visiting Plaza Asia Tasikmalaya. The CR value of reference group variable in influencing hedonic value was 1.945 which met requirements, that was between \pm 2.58 and the probability value was 0.003 which was less than 0.05 . This meant that the reference group had a significant influence on the hedonic value of visitors of Plaza Asia Tasikmalaya. Thus the second hypothesis in this study was proven. This results was in line with research of Dedeoglu, et al (2018) which stated that the influence of the social environment in the shop proved to have a significant impact on the hedonic value. In addition, for some people, shopping had a meaning of getting closer to family members or friends. To test the simultaneous hypothesis between servicescape and reference group effects on the hedonic value of Plaza Asia Tasikmalaya visitors statistically could be tested by the F-test. The result of the calculation of F-count was 223.36 more than F-table 
value (3.04) so that the simultaneous hypothesis of the effect of servicescape and reference groups on the hedonic value was accepted. Thus hypothesis 3 was proven. The results of this study were in line with the research of Sastradhi and Widagda K (2013) which stated that retail atmosphere, including servicescape and reference groups had an influence on hedonic value and impulsive buying.

The servicescape including ambient condition, functionality, explicit cues and implicit cues will attract the attention of visitors to visit. In addition, the good servicescape provided will encourage visitors to make purchases, especially impulsive buying. This finding was based on the CR value of servicescape towards impulsive buying that was 0.605 which met the requirements (between \pm 2.58 ) and the probability value was 0.000 which met the requirements. This meant that the servicescape has an influence on impulsive buying of visitor of Plaza Asia Tasikmalaya. Thus the fourth hypothesis in this study was proven. The results of this study was in line with the research of Herthatie (2012); Yuliantini and Sulistyawati (2013) stated that the servicescape has influence on impulsive buying. Visitors consider suggestions from their social environment which include family, friends, community, idols and others in making purchases. The group referred to visit Plaza Asia Tasikmalaya after gaining good impressions and experiences during their visit. So that the possibility of making impulsive purchases will be even greater. The $\mathrm{CR}$ value of the reference group variable on impulsive buying was 1.230 which met the requirements, which was between \pm 2.58 and the probability value was 0.000 which met the requirements (less than 0.05 ). This meant that the reference group had significant influence on impulsive buying of Plaza Asia Tasikmalaya visitors. Thus the fifth hypothesis in this study was proven. The results of this study was in line with research by Yistiani et al (2012); and Risqiani (2015) which stated that the reference group can influence impulsive buying. To test the simultaneous hypothesis of the effect of servicescape, reference groups and hedonic value on impulsive purchases of Plaza Asia Tasikmalaya visitors statistically, by F-test was used. The result of F count value was 533.58 was more than F-table value (3.04) so that the simultaneous hypothesis of the effect of servicescape, reference groups and hedonic value on impulsive buying was accepted. Thus hypothesis sixth was proven. The results of this study were in line with the research of Sastradhi and Widagda K (2013) which stated that the servicescape and reference groups had an influence on hedonic value and impulsive buying. In addition, according to Rachmawati (2009) consumers are more likely to be involved in impulsive buying when they were motivated by hedonic desires or economic reasons, such as pleasure, fantasy, and social or emotional satisfaction.

\section{Conclussion}

Based on the result, it could be concluded that there was a significant influence of servicescape and reference group variables on the hedonic value of visitors of Plaza Asia Tasikmalaya partially or simultaneously. There was a significant influence of servicescape variables, reference groups and hedonic values on impulsive buying of visitors to Plaza Asia Tasikmalaya partially or simultaneously.

The implication of this research hopefully could contribute to the existing student in enriching management sciences, motivating them in increasing literation skills, such as writing journal and doing the current issues research. For the retailer, especially Plaza Asia Tasikmalaya, this study can be useful in developing servicescape and motivate the consumer/visitor to make reference in determining the hedonic value and impulsive buying. Otherwise, the visitor would feel uncomfortable and annoyed. Thus, they will not back to visit and then never recommend to others. The author also provided some suggestions as follows: (1) Plaza Asia Tasikmalaya should pay attention to the servicescape, related to ambience, explicit cues and implicit cues that caused 
visitors becoming comfortable and getting pleasant; (2) advised to organize activities that can attract the attention of visitors so that interested visitors could provide recommendations to friends/family; (3) improving its facilities and services so that visitors feel comfort and enjoyment. So that they get a good impression when they visit Plaza Asia Tasikmalaya; (4) complement the products offered, provide attractive promotion so that visitors were interested in purchasing products even though they did not need them (Impulsive buying).

This study was taken place in Plaza Asia Tasikmalaya, the biggest mall in East Priangan of West Java. The data collective was by using convenience sampling. The analysis technique included common analysis by Amos program. For the further study must take an action in choosing more supermarkets especially in West Java Indonesia for comparative study in determining hedonic value and impulsive buying and factors affecting them. related to the results, obtained a fairly large coefficient of nondetermination, so that it could be concluded that there were still other variables that affected the hedonic value variable and impulsive buying, and other variables can be tested in further research. So, deep analysis needed to understand customer behaviour especially in hedonic value and impulsive buying.

\section{References}

Asnawati., \& Wahyuni, S. (2018). The Influence of Hedonic Shopping Motivation to The Impulse Buying of Online-Shopping Consumer on Instagram. RJOAS, 2 (74), 99 - 107. DOI: 10.18551/rjoas.2018-02.11

Angga, Y. (2017). 5 Toko Ritel Modern yang Berguguran di 2017. Retrieved September 15, 2020, from https://www.liputan6.com /bisnis/read/3188709/5-toko-ritelmodern-yang-berguguran-di-2017.

Ballantine, P. W., Jack, R., \& Parsons, A. G. (2010). Atmospheric Cues and Their Effect on the Hedonic Retail Experience. International Journal of Retail and Distribution Management, 38 (8), 641 - 653.

Berman, Barry., \& Evans, J. R. (2010). Retail Management: A Strategic Approach. USA: Pearson.

Darma, L. A., \& Japarianto. E. (2014). Analisa Pengaruh Hedonic Shopping Value Terhadap Impulse Buying Dengan Shopping Lifestyle Dan Positive Emotion Sebagai Variabel Intervening Pada Mall Ciputra World Surabaya. Jurnal Manajemen Pemasaran, 8(2). ISSN 1907-235X.

Dedeoglu, B.B ., Bilgihan. A., Ye, B. H., Buonincontri, P., \& Okumus. F. (2018). The Impact of Servicescape on Hedonic Value and Behavioral Intentions: The Importance of Previous Experience. International Journal of Hospitality Management, 72, 10 - 20. https://doi.org/10.1016/j.ijhm.2017.12.007

Herthatie, J. A. (2012). Model Kecenderungan Pembelian Impulsif (Studi pada Konsumen Matahari Departement Store Kota Ambon). Jurnal Manajemen Teknologi, 11(3).

Indrawati. et al. (2017). Perilaku Konsumen Individu Dalam Mengadopsi Layanan Berbasis Teknologi Informasi dan Komunikasi. Bandung: Refika Aditama

Kline, R. B. (2011). Principles and Practice of Structural Equation Modeling (3 ${ }^{\text {rd }}$ Edition). New York: Guilford.

Kotler, P., \& Keller, K. L. (2016). Marketing Management (13rd Edition). Jakarta: Penerbit Erlangga. 
Lin, I. Y. (2016). Effects of Visual Servicescape Aesthetics Comprehension and Appreciation on Consumer Experience. Journal of Services Marketing, 30(7), $692-712$.

Mowen, J. C., \& Minor, M. (2012). Perilaku Konsumen (Edisi ke 5). Jakarta: Erlangga.

Nugraheny, D. E. (2020). Data Kependudukan 2020: Penduduk Indonesia 268.583.016 Jiwa. Retrieved September 18, 2020, from https://nasional.kompas.com/read/2020/08/12/15261351/data-kependudukan2020-penduduk-indonesia-268583016-jiwa?page=all.

Octa, A., Arifin, P. Z., \& Sunarti. (2014). Pengaruh Nilai Belanja Hedonis Terhadap Pembelian Impulsif Pada Toko Online Dengan Emosi Positif Sebagai Variabel Perantara (Studi Pada Mahasiswa/I Program Strata-1 Angkatan 2011/2012 Jurusan Administrasi Bisnis Fakultas Ilmu Administrasi Universitas Brawijaya). Jurnal Administrasi Bisnis (JAB), 8(2), 1 - 10.

Rashid, N. M., Ma'amor, H., Ariffin, N., \& Achim, N. (2015). Servicescape: Understanding How Physical Dimensions Influence Exhibitors Satisfaction in Convention Centre. Pocedia-Social and Behavioral Sciences, 211, 776 - 782.

Risqiani, R. (2015). Antecedents and Consequences of Impulse Buying Behaviour. Business and Entrepreneur Review, 15(1), 1 -20. ISSN: 0853-9189.

Sastradhi, Y. D., \& Widagda, K. I G. N. (2013). Pengaruh Atmosfer Ritel Dan Tekanan Kelompok Referensi Terhadap Nilai Hedonik Dan Pembelian Impulsif. E-Jurnal Manajemen, $3(2), \quad 386 \quad$ 400, https://ojs.unud.ac.id/index.php/Manajemen/article/view/6795.

Santoso, S. (2015). AMOS 22 untuk Structural Equation Modeling (Konsep Dasar Aplikasi). Jakarta: Elex Media Komputindo.

Schiffman, L. G., \& Kanuk, L. L. (2010). Consumer Behaviour (10 ${ }^{\text {th }}$ edition). New Jersey: Pearson.

Thomas. (2016). Mendag: 50 Persen Orang Indonesia Sangat Konsumtif. Retrieved September 18, 2020, from https://www.viva.co.id/arsip/765421-mendag-50persen-orang-indonesia-sangat-konsumtif.

Utami, C. W. (2010). Manajemen Ritel: Strategi dan Implementasi Ritel Modern. Jakarta: Salemba Empat.

Yistiani, N. N. M., Yasa, N. N. K., \& Suasana, I G. A. (2012). Pengaruh Atmosfer Gerai Dan Pelayanan Ritel Terhadap Nilai Hedonik Dan Pembelian Impulsif Pelanggan Matahari Department Store Duta Plaza Di Denpasar. Jurnal Manajemen, Strategi Bisnis, dan Kewirausahaan, 6(2), 1 - 10.

Yuliartini, N. P. E., \& Sulistyawati, E. (2013). Pengaruh Stimulus Lingkungan Toko Dan Faktor Lingkungan Sosial Terhadap Perilaku Pembelian Impulsif Pada Carrefour Sunset Road Di Denpasar. Universitas Udayana: Bali.

Zeithaml, V. A., Bitner, M. J., \& Gremler, D. D. (2009). Services marketing: Integrating Customer Focus across the Firm. Boston: McGraw-Hill. 